\title{
KOMBINASI METODE ANALYTICAL HIERARCHY PROCESS (AHP) DAN METODE SIMPLE ADDITIVE WEIGHTING (SAW) PADA PENILAIAN KINERJA DOSEN
}

\author{
${ }^{1}$ Fitra Ramadona, ${ }^{2}$ Usman \\ 1,2, Program Studi Sistem Informasi, Fakultas Teknik dan Ilmu Komputer \\ Universitas Islam Indragiri (UNISI) \\ Jl. Provinsi No. 01 Tembilahan Hulu, Indragiri Hilir, Riau - Indonesia \\ Email:fitra ramadona@yahoo.com, usmanovsky13411@yahoo.com
}

\begin{abstract}
Universitas Islam Indragiri (UNISI) adalah Universitas swasta yang terdapat di kota Tembilahan, Riau yang selalu berupaya dalam peningkatan mutu internal secara berkelanjutan agar dapat bersaing dengan perguruan tinggi lain. Salah satu upaya yang telah dilakukan adalah dengan melakukan penilaian terhadap kinerja dosen. Proses penilaian tersebut masih dilakukan secara manual dan diimplementasikan dalam bentuk excel, sehingga memerlukan waktu yang cukup lama untuk melakukan pengolahan data. Pengolahan data yang dilakukan pun masih banyak terjadi kesalahan, seperti kesalahan dalam perhitungan dan penyajian laporan. Dalam penelitian ini dirancancang sebuah sistem pendukung keputusan dengan menggunakan metode Analytical Hierarchy Process (AHP) sebagai metode pembobotan masing-masing kriteria dan metode Simple Additive Weighting (SAW) sebagai metode perangkingan. Kriteria yang digunakan untuk penilaian kinerja dosen ini adalah tingkat kehadiran mengajar, ketepatan mulai dan mengakhiri kuliah, kesesuaian meteri dengan silabus, kemudahan penyampaian materi untuk dipahami, menggunakan alat bantu untuk memperjelas materi, malayani dan memberikan perhatian dalam komunikasi dua arah, membantu dan mudah untuk ditemui di luar waktu perkuliahan, memiliki pengetahuan aktual dalam pembelajaran. Dan alternatif yang digunakan adalah dosen-dosen yang telah terdaftar di Dikti dan masih aktif mengajar pada semester genap tahun ajaran 2015. Implementasi sistem pendukung keputusan ini menggunakan bahasa pemrograman Microsoft Visual Basic 6.0 dan database MySQL.
\end{abstract}

Kata kunci: UNISI, SPK, AHP, SAW, Penilaian Kinerja Dosen.

\section{PENDAHULUAN}

Pada setiap instansi, kegiatan penilaian terhadap kinerja kayawan menggunakan kegiatan yang umum dilakukan. Demikian pula dalam instansi perguruan tinggi, baik berbentuk Universitas maupun sekolah tinggi dianggap perlu dilakukan penilaian terhadap kinerja karyawannya, dalam hal ini adalah dosen. Penilaian tersebut dilakukan untuk mengetahui pengaruh pengajaran dosen terhadap mahasiswa. Peran dosen sebagai pengajar dalam proses belajar mengajar sangatlah penting, dosen menjadi tumpuan utama dalam transformasi ilmu yang diberikan oleh pihak instansi pendidikan kepada para mahasiswanya. Universitas Islam Indragiri (UNISI) adalah Universitas swasta yang terdapat di kota Tembilahan, Riau yang selalu berupaya dalam peningkatan mutu internal secara berkelanjutan agar dapat bersaing dengan perguruan tinggi lain. Salah satu upaya yang telah dilakukan adalah dengan melakukan penilaian terhadap kinerja dosen. Penilaian dilakukan setiap akhir semester dengan membagikan kuesioner penilaian kinerja dosen kepada mahasiswa. Proses penilaian tersebut masih dilakukan secara manual dan diimplementasikan dalam bentuk excel, sehingga memerlukan waktu yang cukup lama untuk melakukan pengolahan data. Pengolahan data yang dilakukan pun masih banyak terjadi kesalahan, seperti kesalahan dalam perhitungan dan penyajian laporan. Untuk mendukung penilaian kinerja dosen, maka dibutuhkan sistem pendukung keputusan untuk menentukan keputusan yang diambil. Banyak metode yang dapat digunakan dalam sistem pengambilan keputusan. Beberapa diantaranya adalah metode Analytical Hierarchy Process (AHP) dan metode Simple Additive Weighting (SAW). Namun kedua metode tersebut masih memiliki kekurangan, kekurangan metode AHP ialah sulitnya 
menentukan besarnya prioritas antar kriteria karena tiap orang memiliki persepsi sendiri mengenai prioritas yang ada (Kurniady \& Munggana, 2013), dan kekurangan metode SAW ialah metode ini mengharuskan pembuat keputusan menentukan bobot dari setiap atribut (Zulita, 2013).

\section{TINJAUAN PUSTAKA}

Sistem pendukung keputusan merupakan sistem informasi interaktif yang menyediakan informasi, pemodelan dan pemanipulasian data. Sistem itu digunakan untuk membantu pengambilan keputusan dalam situasi yang semiterstruktur dan situasi yang tidak terstruktur, dimana tak seorang pun tahu sacara pasti bagaimana keputusan seharusnya dibuat (Alter dalam Kusrini, 2007). Sistem pendukung keputusan biasanya dibangun untuk mendukung solusi atas suatu masalah atau untuk mengevaluasi suatu peluang. Sistem pendukung keputusan yang seperti itu disebut aplikasi Sistem pendukung keputusan. Aplikasi Sistem pendukung keputusan digunakan dalam pengambilan keputusan. Aplikasi menggunakan CBIS (Computer Based Information System) yang fleksibel, interaktif, dan dapat diadaptasi,yang dikembangkan untuk mendukung solusi atas masalah manajemen spesifik yang tidak terstruktur. Aplikasi Sistem pendukung keputusan menggunakan data, memberikan antar muka pengguna yang mudah, dan dapat menggabungkan pemikiran pengambilan keputusan. Sistem pendukung keputusan lebih ditujukan untuk mendukung manajemen dalam melakukan pekerjaan yang bersifat analitis dalam situasi yang kurang terstruktur dan dengan kriteria yang kurang jelas. Sistem pendukung keputusan tidak dimaksudkan unutk mengotomatisasikan pengambilan keputusan, tetapi memberikan perangkat interaktif yang memungkinkan pengambilan keputusan untuk melakukan berbagai analisis menggunakan model-model yang tersedia (Kusrini, 2007).

Metode AHP merupakan salah satu model untuk pengambilan keputusan yang dapat membantu kerangka berfikir manusia. Metode ini mula-mula dikembangkan oleh Thomas L. Saaty pada tahun 70-an. Dasar berpikirnya metode AHP adalah proses membentuk skor secara numeric untuk menyusun rangking setiap alternatif keputusan berbasis pada bagaimana sebaiknya alternative itu dicocokkan dengan kriteria pembuat keputusan. Adapun struktur hirarki AHP ditampilkan pada Gambar 1 di bawah ini.

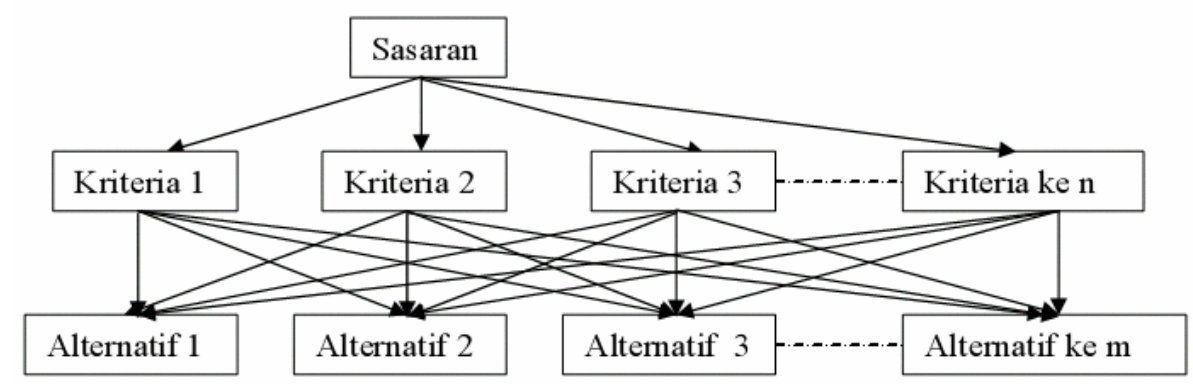

Gambar 1 Struktur Hirarki AHP

Adapun langkah-langkah metode AHP adalah: (1). Menentukan jenis-jenis kriteria yang akan dipilih; (2). Menyusun kriteria-kriteria tersebut dalam bentuk matriks berpasangan; (3). Menjumlah matriks kolom; (4). Menghitung nilai elemen kolom kriteria dengan rumus masing-masing elemen kolom dibagi dengan jumlah matriks kolom; (5). Menghitung nilai prioritas kriteria dengan rumus menjumlah matriks baris hasil langkah ke 4 dan hasilnya 5 dibagi dengan jumlah kriteria; (6). Menentukan alternatif-alternatif yang akan menjadi pilihan; (7). Menyusun alternatif-alternatif yang telah ditentukan dalam bentuk matriks berpasangan untuk masing-masing kriteria. Sehingga akan ada sebanyak $n$ buah matriks berpasangan antar alternatif; (8). Masing-masing matriks berpasangan antar alternatif sebanyak $n$ buah matriks, masing-masing matriksnya dijumlah per kolomnya; (9). Menghitung nilai prioritas alternatif masing-masing matriks berpasangan antar alternatif dengan rumus seperti langkah 4 dan langkah 5; (10). Menguji konsistensi setiap matriks 
berpasangan antar alternatif dengan rumus masing-masing elemen matriks berpasangan pada langkah 2 dikalikan dengan nilai prioritas kriteria. Hasilnya masing-masing baris dijumlah, kemudian hasilnya dibagi dengan masing-masing nilai prioritas criteria; (11). Menghitung Lamda max dengan rumus;

$$
\lambda \max =\frac{\Sigma \lambda}{n}
$$

(12). Menghitung $\mathrm{Cl}$ dengan rumus;

$$
C I=\frac{\lambda \max -n}{n-1}
$$

(13). Menghitung CR dengan rumus;

$$
C R=\frac{C I}{I R}
$$

Dimana IR adalah nilai yang berasal dari tabel random seperti tabel 2.1.

\section{Tabel 1 Nilai IR}

\begin{tabular}{|l|l|l|l|l|l|l|l|l|l|l|}
\hline $\mathrm{n}$ & 1 & 2 & 3 & 4 & 5 & 6 & 7 & 8 & 9 & 10 \\
\hline $\mathrm{IR}$ & 0.00 & 0.00 & 0.58 & 0.90 & 1.12 & 1.24 & 1.32 & 1.41 & 1.45 & 1.49 \\
\hline
\end{tabular}

Jika $C R<0,1$ maka nilai perbandingan berpasangan pada matriks kriteria yang diberikan konsisten. Jika $C R \geq 01$, maka nilai perbandingan berpasangan pada matriks kriteria yang diberikan tidak konsisten. Sehingga jika tidak konsisten, maka pengisian nilai-nilai pada matriks berpasangan pada unsur kriteria maupun alternatif harus diulang; (14). Menyusun matriks baris antara alternatif versus kriteria yang isinya hasil perhitungan proses langkah 7, langkah 8 dan langkah 9; (15). Hasil akhirnya berupa prioritas global sebagai nilai yang digunakan oleh pengambil keputusan berdasarkan skor yang tertinggi (Supriyono dkk, 2007).

Dalam penilaian kriteria dan alternatif menurut Saaty (1983), untuk berbagai persoalan, skala 1 sampai 9 adalah skala terbaik dalam mengekspresikan pendapat. Nilai dan definisi pendapat kualitatif dari skala perbandingan Saaty dapat dilihat pada tabel 2.2.

Tabel 2 Nilai Definisi Pendapat Kualitatif dari Skala Perbandingan Saaty (1983)

\begin{tabular}{|l|l|}
\hline Nilai & Keterangan \\
\hline 1 & Kriteria A sama penting dengan Kriteria B \\
3 & A sedikit lebih penting dari B \\
5 & A jelas lebih penting dari B \\
7 & A sangat jelas lebih penting dari B \\
9 & A mutlak lebih penting dari B \\
$2,4,6,8$ & Apabila ragu-ragu antara dua nilai yang \\
& berdekatan \\
\hline
\end{tabular}

Nilai perbandingan A dengan B adalah 1 (satu) dibagi dengan nilai perbandingan B dengan A (Asfi \& Sari, 2010).

Metode Simple Additive Weighting (SAW) sering juga dikenal istilah metode penjumlahan terbobot. Konsep dasar metode SAW adalah mencari penjumlahan terbobot dari rating kinerja pada setiap alternatif pada semua atribut (Fishburn, 1967) (MacCrimmon, 1968). Metode SAW membutuhkan proses normalisasi matriks keputusan $(X)$ ke suatu skala yang dapat diperbandingkan dengan semua rating alternatif yang ada. Metode SAW ini mengharuskan pembuat keputusan menentukan bobot bagi setiap atribut. Skor total untuk alternatif diperoleh dengan menjumlahkan seluruh hasil perkalian antara rating (yang dapat dibandingkan lintas 
atribut) dan bobot tiap atribut. Rating tiap atribut haruslah bebas dimensi dalam arti telah melewati proses normalisasi matriks sebelumnya (Tobing, 2014).

Adapun langkah penyelesaian dalam menggunakannya adalah: (1). Menentukan alternatif, yaitu $\mathrm{A}_{\mathrm{i}}$; (2). Menentukan kriteria yang akan dijadikan acuan dalam pengambilan keputusan, yaitu $\mathrm{C}_{\mathrm{i}}$; (3). Memberikan nilai rating kecocokan tiap alternatif pada setiap kriteria; (4). Menentukan bobot preferensi atau tingkat kepentingan (W) setiap kriteria;

$$
W=w_{1}, w_{2}, w_{3}, \ldots, w_{j}
$$

(5). Membuat tabel rating kecocokan dari setiap alternatif pada setiap kriteria; (6). Membuat matriks keputusan $(X)$ yang dibentuk dari tabel rating kecocokan dari setiap alternatif pada setiap kriteria. Nilai $X$ setiap alternatif $\left(A_{i}\right)$ pada setiap kriteria $\left(C_{j}\right)$ yang sudah ditentukan, dimana, $\mathrm{i}=1,2, \ldots \mathrm{m}$ dan $\mathrm{j}=1,2, \ldots \mathrm{n}$;

$$
X=\left[\begin{array}{ccc}
x_{11} & \ldots & x_{1 j} \\
\ldots & \ldots & \ldots \\
x_{i 1} & \ldots & x_{i j}
\end{array}\right]
$$

(7). Melakukan normalisasi matrik keputusan dengan cara menghitung nilai rating kinerja ternomalisasi $\left(r_{i j}\right)$ dari alternatif $A_{i}$ pada kriteria $C_{j}$;

$$
r_{i j}=\left\{\begin{array}{l}
\frac{x_{i j}}{\operatorname{Max} x_{i j}} \text { jika } j \text { atribut keuangan (benefit) } \\
\frac{\text { Min } x_{i j}}{x_{i j}} \text { jika j atribut biaya (cost) }
\end{array}\right.
$$

Keterangan: (a). Kriteria keuntungan apabila nilai memberikan keuntungan bagi pengambil keputusan, sebaliknya kriteria biaya apabila menimbulkan biaya bagi pengambil keputusan; (b). Apabila berupa kriteria keuntungan maka nilai dibagi dengan nilai dari setiap kolom, sedangkan untuk kriteria biaya, nilai dari setiap kolom dibagi dengan nilai; (8). Hasil dari nilai rating kinerja ternomalisasi $\left(r_{i j}\right)$ membentuk matriks ternormalisasi $(R)$;

$$
R=\left[\begin{array}{ccc}
r_{11} & \ldots & r_{1 j} \\
\ldots & \ldots & \ldots \\
r_{i 1} & \ldots & r_{i j}
\end{array}\right]
$$

(9). Hasil akhir nilai preferensi $\left(V_{i}\right)$ diperoleh dari penjumlahan dari perkalian elemen baris matriks ternormalisasi $(\mathrm{R})$ dengan bobot preferensi $(\mathrm{W})$ yang bersesuaian eleman kolom matriks (W);

$$
V_{i}=\sum_{j=1}^{n} w_{j} r_{i j}
$$

(10). Hasil perhitungan nilai $V_{i}$ yang lebih besar mengindikasikan bahwa alternatif $A_{i}$ merupakan alternatif terbaik (Kusumadewi dalam Usito, 2013);

\section{PERANCANGAN}

Sistem pendukung keputusan yang akan dirancang pada penilaian kinerja dosen ini memiliki dua tahapan, yaitu tahap pembobotan masing-masing kriteria menggunakan metode AHP, dan tahap perangkingan menggunakan metode SAW.

\subsection{Pembobotan Menggunakan Metode AHP}

Masukan awal adalah menentukan matriks perbandingan berpasangan. Dapat dilihat pada Tabel 3 . 
Tabel 3 Matriks Perbandingan Berpasangan

\begin{tabular}{|l|l|l|l|l|l|l|l|l|}
\hline & $C_{1}$ & $C_{2}$ & $C_{3}$ & $C_{4}$ & $C_{5}$ & $C 6$ & $C 7$ & $C 8$ \\
\hline$C_{1}$ & 1 & 2 & 2 & 2 & 3 & 3 & 3 & 2 \\
\hline$C_{2}$ & & 1 & 1 & 1 & 3 & 2 & 3 & 1 \\
\hline$C_{3}$ & & & 1 & 1 & 3 & 2 & 3 & 1 \\
\hline$C 4$ & & & & 1 & 3 & 2 & 3 & 1 \\
\hline$C 5$ & & & & & 1 & $1 / 3$ & 1 & $1 / 4$ \\
\hline$C 6$ & & & & & & 1 & 5 & $1 / 3$ \\
\hline$C 7$ & & & & & & & 1 & $1 / 2$ \\
\hline$C 8$ & & & & & & & & 1 \\
\hline
\end{tabular}

Setelah menentukan matriks perbandingan berpasangan pada Tabel 3 di atas, maka selanjutnya lakukan penjumlahan perkolom. Hasilnya ditampilkan pada Tabel 4.

Tabel 4 Nilai Jumlah Kolom

\begin{tabular}{|l|l|l|l|l|l|l|l|l|}
\hline & $C 1$ & $C 2$ & $C_{3}$ & $C_{4}$ & $C_{5}$ & $C 6$ & $C 7$ & $C 8$ \\
\hline$C 1$ & 1.000 & 2.000 & 2.000 & 2.000 & 3.000 & 3.000 & 3.000 & 2.000 \\
\hline$C 2$ & 0.500 & 1.000 & 1.000 & 1.000 & 3.000 & 2.000 & 3.000 & 1.000 \\
\hline$C 3$ & 0.500 & 1.000 & 1.000 & 1.000 & 3.000 & 2.000 & 3.000 & 1.000 \\
\hline$C 4$ & 0.500 & 1.000 & 1.000 & 1.000 & 3.000 & 2.000 & 3.000 & 1.000 \\
\hline$C 5$ & 0.333 & 0.333 & 0.333 & 0.333 & 1.000 & 0.333 & 1.000 & 0.250 \\
\hline$C 6$ & 0.333 & 0.500 & 0.500 & 0.500 & 3.000 & 1.000 & 5.000 & 0.333 \\
\hline$C 7$ & 0.333 & 0.333 & 0.333 & 0.333 & 1.000 & 0.200 & 1.000 & 0.500 \\
\hline$C 8$ & 0.500 & 1.000 & 1.000 & 1.000 & 4.000 & 3.000 & 2.000 & 1.000 \\
\hline $\begin{array}{l}\text { Jumlah } \\
\text { Kolom }\end{array}$ & 4.000 & 7.167 & 7.167 & 7.167 & $\mathbf{2 1 . 0 0 0}$ & 13.533 & $\mathbf{2 1 . 0 0 0}$ & 7.083 \\
\hline
\end{tabular}

Setelah didapatkan nilai jumlah kolom pada Tabel 4 di atas, maka selanjutnya lakukan normalisasi matriks dengan rumus masing-masing elemen kolom pada Tabel 4 di atas dibagi dengan jumlah kolom masing-masingnya, lalu jumlahkan perbaris. Hasilnya ditampilkan pada Tabel 5 .

Tabel 5 Normalisasi Matriks

\begin{tabular}{|l|l|l|l|l|l|l|l|l|l|}
\hline & $C 1$ & $C 2$ & $C 3$ & $C 4$ & $C_{5}$ & $C 6$ & $C 7$ & $C 8$ & $\begin{array}{l}\text { Jumlah } \\
\text { Baris }\end{array}$ \\
\hline C1 & 0.250 & 0.279 & 0.279 & 0.279 & 0.143 & 0.222 & 0.143 & 0.282 & $\mathbf{1 . 8 7 7}$ \\
\hline C2 & 0.125 & 0.140 & 0.140 & 0.140 & 0.143 & 0.148 & 0.143 & 0.141 & $\mathbf{1 . 1 1 8}$ \\
\hline C3 & 0.125 & 0.140 & 0.140 & 0.140 & 0.143 & 0.148 & 0.143 & 0.141 & $\mathbf{1 . 1 1 8}$ \\
\hline C4 & 0.125 & 0.140 & 0.140 & 0.140 & 0.143 & 0.148 & 0.143 & 0.141 & $\mathbf{1 . 1 1 8}$ \\
\hline C5 & 0.083 & 0.047 & 0.047 & 0.047 & 0.048 & 0.025 & 0.048 & 0.035 & $\mathbf{0 . 3 7 8}$ \\
\hline C6 & 0.083 & 0.070 & 0.070 & 0.070 & 0.143 & 0.074 & 0.238 & 0.047 & $\mathbf{0 . 7 9 5}$ \\
\hline C7 & 0.083 & 0.047 & 0.047 & 0.047 & 0.048 & 0.015 & 0.048 & 0.071 & $\mathbf{0 . 4 0 3}$ \\
\hline C8 & 0.125 & 0.140 & 0.140 & 0.140 & 0.190 & 0.222 & 0.095 & 0.141 & $\mathbf{1 . 1 9 2}$ \\
\hline
\end{tabular}

Setelah didapatkan normalisasi matriks pada Tabel 5 di atas, maka selanjutnya lakukan pembobotan dengan rumus masing-masing elemen jumlah baris pada Tabel 5 di atas dibagi dengan banyaknya kriteria ( $n$ ). Maka didapatkanlah hasil pembobotan masing masing kriteria. Dan hasilnya adalah sebagai berikut:

$$
\text { Bobot } C_{1}=\frac{1.877}{8}=0.235 \quad \text { Bobot } C_{5}=\frac{0.378}{8}=0.047
$$




$$
\begin{array}{ll}
\text { Bobot } C_{2}=\frac{1.118}{8}=0.140 & \text { Bobot } C_{6}=\frac{0.795}{8}=0.099 \\
\text { Bobot } C_{3}=\frac{1.118}{8}=0.140 & \text { Bobot } C_{7}=\frac{0.403}{8}=0.050 \\
\text { Bobot } C_{4}=\frac{1.118}{8}=0.140 & \text { Bobot } C_{8}=\frac{1.192}{8}=0.149
\end{array}
$$

Hitung nilai Lamda max, $\mathrm{Cl}$, dan $\mathrm{CR}$ untuk menentukan konsistensinya. Untuk mencari nilai $\mathrm{CR}$, IRnya harus sesuai dengan Tabel 1. Dan hasilnya adalah sebagai berikut:

$$
\begin{aligned}
& \lambda \max =\frac{\Sigma \lambda}{n} \\
& C I=\frac{\lambda \max -n}{n-1} \\
& C R=\frac{C I}{I R} \\
& =\frac{66.844}{8} \\
& =\frac{0.355}{7} \\
& =\frac{0.051}{1.41} \\
& =8.355 \\
& =0.051 \\
& =0.04
\end{aligned}
$$

Nilai Consistency Ratio $(C R)$ yang didapat $<0.1$, yang berarti bahwa bobot kriteria yang dihasilkan layak untuk digunakan.

\subsection{Perangkingan Menggunakan Metode SAW}

Nilai rating kecocokan tiap alternatif pada setiap kriteria. Dapat dilihat pada Tabel 6.

Tabel 6 Nilai Rating Kecocokan Alternatif terhadap Kriteria

\begin{tabular}{|l|l|l|l|l|l|l|l|l|}
\hline & $\mathrm{C} 1$ & $\mathrm{C} 2$ & $\mathrm{C} 3$ & $\mathrm{C} 4$ & $\mathrm{C} 5$ & $\mathrm{C} 6$ & $\mathrm{C} 7$ & $\mathrm{C} 8$ \\
\hline $\mathrm{A} 1$ & 5 & 5 & 5 & 4 & 5 & 5 & 4 & 4 \\
\hline $\mathrm{A} 2$ & 4 & 4 & 5 & 5 & 5 & 5 & 5 & 4 \\
\hline $\mathrm{A} 3$ & 4 & 3 & 4 & 3 & 3 & 4 & 4 & 4 \\
\hline $\mathrm{A} 4$ & 4 & 3 & 4 & 4 & 3 & 4 & 3 & 4 \\
\hline $\mathrm{A} 5$ & 4 & 3 & 5 & 4 & 5 & 3 & 4 & 5 \\
\hline $\mathrm{A} 6$ & 3 & 2 & 4 & 4 & 3 & 3 & 4 & 5 \\
\hline $\mathrm{A} 7$ & 3 & 4 & 4 & 3 & 3 & 3 & 4 & 4 \\
\hline $\mathrm{A} 8$ & 3 & 4 & 4 & 3 & 4 & 5 & 3 & 4 \\
\hline A9 & 4 & 5 & 4 & 3 & 3 & 4 & 5 & 4 \\
\hline $\mathrm{A} 10$ & 4 & 5 & 4 & 4 & 5 & 4 & 3 & 5 \\
\hline A11 & 4 & 5 & 5 & 5 & 5 & 5 & 5 & 5 \\
\hline $\mathrm{A} 12$ & 4 & 4 & 3 & 4 & 4 & 3 & 5 & 4 \\
\hline $\mathrm{A} 13$ & 5 & 5 & 5 & 5 & 4 & 5 & 5 & 5 \\
\hline $\mathrm{A} 14$ & 5 & 5 & 5 & 4 & 3 & 5 & 3 & 5 \\
\hline A15 & 4 & 4 & 5 & 5 & 4 & 5 & 5 & 5 \\
\hline A16 & 3 & 3 & 4 & 4 & 3 & 4 & 3 & 5 \\
\hline A17 & 4 & 4 & 4 & 4 & 5 & 5 & 5 & 4 \\
\hline A18 & 5 & 5 & 5 & 4 & 4 & 5 & 5 & 5 \\
\hline A19 & 3 & 3 & 4 & 3 & 3 & 4 & 3 & 4 \\
\hline A20 & 4 & 5 & 3 & 5 & 4 & 5 & 3 & 5 \\
\hline A21 & 4 & 4 & 5 & 4 & 4 & 3 & 4 & 3 \\
\hline A22 & 5 & 5 & 5 & 4 & 4 & 3 & 4 & 5 \\
\hline
\end{tabular}

Melakukan normalisasi matriks keputusan dengan cara menghitung nilai rating kinerja ternomalisasi $\left(r_{i j}\right)$ dari alternatif $\left(A_{i}\right)$ pada kriteria $\left(C_{i}\right)$.

$$
r_{i j}=\frac{x_{i j}}{\operatorname{Max} x_{i j}}
$$

Ramadona, Kombinasi Metode Analytical Hierarchy Process (AHP) Dan Metode Simple Additive Weighting (SAW) Pada Penilaian Kinerja Dosen 
Rumus diatas adalah rumus yang digunakan untuk menghitung kriteria benefit. Yang dimaksud dengan benefit adalah jika nilai terbesar adalah yang terbaik. Dapat dilihat pada Tabel 7.

Tabel 7 Normalisasi Matriks Keputusan

\begin{tabular}{|l|l|l|l|l|l|l|l|l|}
\hline & $\mathrm{C} 1$ & $\mathrm{C} 2$ & $\mathrm{C} 3$ & $\mathrm{C} 4$ & $\mathrm{C} 5$ & $\mathrm{C6}$ & $\mathrm{C} 7$ & $\mathrm{C} 8$ \\
\hline $\mathrm{A} 1$ & 1.0 & 1.0 & 1.0 & 0.8 & 1.0 & 1.0 & 0.8 & 0.8 \\
\hline $\mathrm{A} 2$ & 0.8 & 0.8 & 1.0 & 1.0 & 1.0 & 1.0 & 1.0 & 0.8 \\
\hline $\mathrm{A} 3$ & 0.8 & 0.6 & 0.8 & 0.6 & 0.6 & 0.8 & 0.8 & 0.8 \\
\hline $\mathrm{A} 4$ & 0.8 & 0.6 & 0.8 & 0.8 & 0.6 & 0.8 & 0.6 & 0.8 \\
\hline $\mathrm{A} 5$ & 0.8 & 0.6 & 1.0 & 0.8 & 1.0 & 0.6 & 0.8 & 1.0 \\
\hline $\mathrm{A} 6$ & 0.6 & 0.4 & 0.8 & 0.8 & 0.6 & 0.6 & 0.8 & 1.0 \\
\hline $\mathrm{A} 7$ & 0.6 & 0.8 & 0.8 & 0.6 & 0.6 & 0.6 & 0.8 & 0.8 \\
\hline $\mathrm{A} 8$ & 0.6 & 0.8 & 0.8 & 0.6 & 0.8 & 1.0 & 0.6 & 0.8 \\
\hline A9 & 0.8 & 1.0 & 0.8 & 0.6 & 0.6 & 0.8 & 1.0 & 0.8 \\
\hline A10 & 0.8 & 1.0 & 0.8 & 0.8 & 1.0 & 0.8 & 0.6 & 1.0 \\
\hline A11 & 0.8 & 1.0 & 1.0 & 1.0 & 1.0 & 1.0 & 1.0 & 1.0 \\
\hline A12 & 0.8 & 0.8 & 0.6 & 0.8 & 0.8 & 0.6 & 1.0 & 0.8 \\
\hline A13 & 1.0 & 1.0 & 1.0 & 1.0 & 0.8 & 1.0 & 1.0 & 1.0 \\
\hline A14 & 1.0 & 1.0 & 1.0 & 0.8 & 0.6 & 1.0 & 0.6 & 1.0 \\
\hline A15 & 0.8 & 0.8 & 1.0 & 1.0 & 0.8 & 1.0 & 1.0 & 1.0 \\
\hline A16 & 0.6 & 0.6 & 0.8 & 0.8 & 0.6 & 0.8 & 0.6 & 1.0 \\
\hline A17 & 0.8 & 0.8 & 0.8 & 0.8 & 1.0 & 1.0 & 1.0 & 0.8 \\
\hline A18 & 1.0 & 1.0 & 1.0 & 0.8 & 0.8 & 1.0 & 1.0 & 1.0 \\
\hline A19 & 0.6 & 0.6 & 0.8 & 0.6 & 0.6 & 0.8 & 0.6 & 0.8 \\
\hline A20 & 0.8 & 1.0 & 0.6 & 1.0 & 0.8 & 1.0 & 0.6 & 1.0 \\
\hline A21 & 0.8 & 0.8 & 1.0 & 0.8 & 0.8 & 0.6 & 0.8 & 0.6 \\
\hline A22 & 1.0 & 1.0 & 1.0 & 0.8 & 0.8 & 0.6 & 0.8 & 1.0 \\
\hline
\end{tabular}

Nilai preferensi untuk setiap alternatif merupakan hasil penjumlahan dari perkalian normalisasi matriks keputusan dengan bobot kriteria. Hasil Perangkingan dapat dilihat pada Tabel 8.

Tabel 8 Perangkingan

\begin{tabular}{|l|l|l|l|l|l|}
\hline Nama Dosen & Nilai & Ranking \\
\hline Abdullah & 0.932 & 5 \\
\hline Akbar Alfa & 0.895 & 8 \\
\hline Andi Yusapri & 0.735 & 19 \\
\hline Dwi Sushanty & 0.753 & 16 \\
\hline Dwi Yuli Prasetyo & 0.819 & 12 \\
\hline $\begin{array}{l}\text { Gunawan } \\
\text { Syahrantau }\end{array}$ & 0.698 & 20 \\
\hline Hadra Fi Ahlina & 0.696 & 21 \\
\hline Hermiza Mardesci & 0.735 & 18 \\
\hline Ilyas & 0.801 & 13 \\
\hline Indah Sari & 0.857 & 10 \\
\hline M. Gazali M. & 0.953 & 3 \\
\hline Partini & 0.762 & 15 \\
\hline Retty Ninsix & 0.991 & 1 \\
\hline Rifni Nazal Thaher & 0.991 & 1 \\
\hline Abdullah & 0.963 & 2 \\
\hline $\begin{array}{l}\text { Roberta } \\
\text { Surya }\end{array}$ & 0.953 & 3 \\
\hline Zahlul Ikhsan & 0.932 & 5 \\
\hline Akbar Alfa & 0.916 & 6 \\
\hline Usman & 0.895 & 7 \\
\hline Indah Sari & 0.868 & 9 \\
\hline Siti Wardah & 0.857 & 10 \\
\hline Dwi Yuli Prasetyo & 0.839 & 11 \\
\hline Ilyas & 0.819 & 12 \\
\hline
\end{tabular}




\begin{tabular}{|l|l|l|} 
Rifni Novitasari & 0.933 & 4 \\
\hline $\begin{array}{l}\text { Roberta Zulfhi } \\
\text { Surya }\end{array}$ & 0.916 & 6 \\
\hline Samsudin & 0.735 & 17 \\
\hline Siti Wardah & 0.839 & 11 \\
\hline Syafrizal Thaher & 0.963 & 2 \\
\hline Syaiful Ramadhan H. & 0.678 & 22 \\
\hline Usman & 0.868 & 9 \\
\hline Yeni Afriza & 0.778 & 14 \\
\hline Zahlul Ikhsan & 0.913 & 7 \\
\hline
\end{tabular}

\begin{tabular}{|l|l|l|} 
Yeni Afriza & 0.778 & 14 \\
\hline Partini & 0.762 & 15 \\
\hline Dwi Sushanty & 0.753 & 16 \\
\hline Samsudin & 0.735 & 17 \\
\hline Hermiza Mardesci & 0.735 & 18 \\
\hline Andi Yusapri & 0.735 & 19 \\
\hline $\begin{array}{l}\text { Gunawan } \\
\text { Syahrantau }\end{array}$ & 0.698 & 20 \\
\hline Hadra Fi Ahlina & 0.696 & 21 \\
\hline $\begin{array}{l}\text { Syaiful Ramadhan } \\
\text { H. }\end{array}$ & 0.678 & 22 \\
\hline
\end{tabular}

Dari Tabel 8 di atas dihasilkan perangkingan untuk masing-masing dosen. Dosen dengan nilai tertinggi adalah Retty Ninsix sebesar 0.991 dan yang terendah adalah Saiful Ramadhan Harahap sebesar 0.678 .

\section{IMPLEMENTASI}

Implementasi merupakan tahapan penerapkan dan mengoprasikan sistem pada keadaan yang sebenarnya, sehingga akan diketahui apakah sistem yang telah dibangun benar-benar dapat berjalan dan sesuai dengan tujuan yang ingin dicapai. Aplikasi yang digunakan dalam penelitian ini menggunakan Microsoft Visual Basic 6.0 dan penyimpanan database menggunakan MySQL.

\subsection{Form Menu Utama 1}

Form menu utama 1 berfungsi sebagai interface yang memudahkan pengguna untuk memilih menu untuk membuat file baru dan membuka file yang telah tersimpan. Dapat dilihat pada Gambar 2.

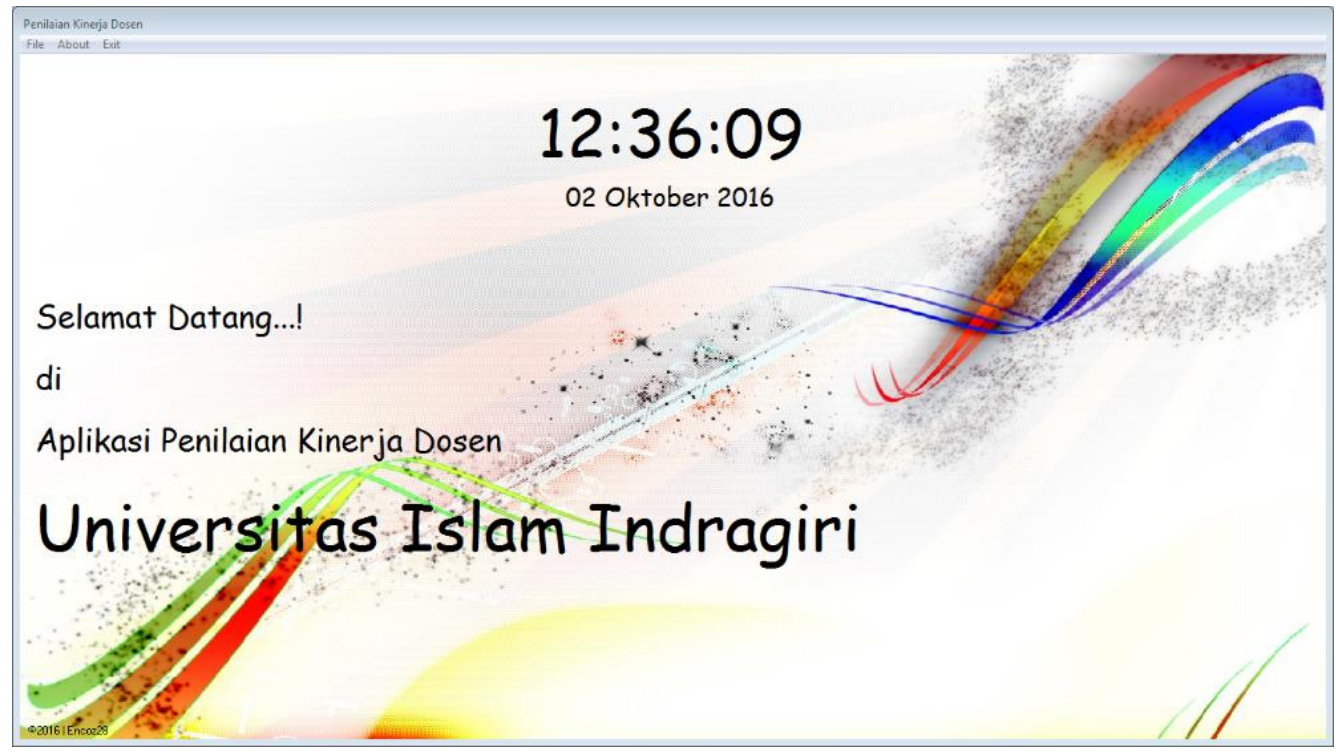

\section{Gambar 2 Form Menu Utama 1}

\subsection{Form New}

Form new berfungsi untuk membuat file baru yang akan dihitung. Dapat dilihat pada Gambar 3. 


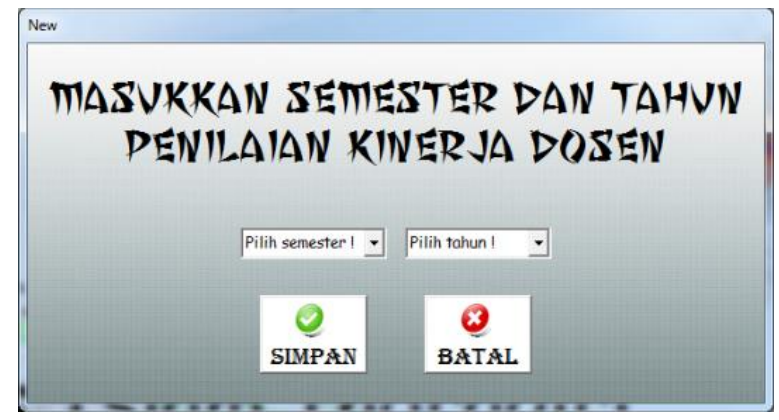

Gambar 3 Form New

\subsection{Form Menu Utama 2}

Form menu utama 2 berfungsi sebagai interface yang memudahkan pengguna untuk memilih menu, karena semua menu perhitungan ada pada menu utama 2. Dapat dilihat pada Gambar 4.

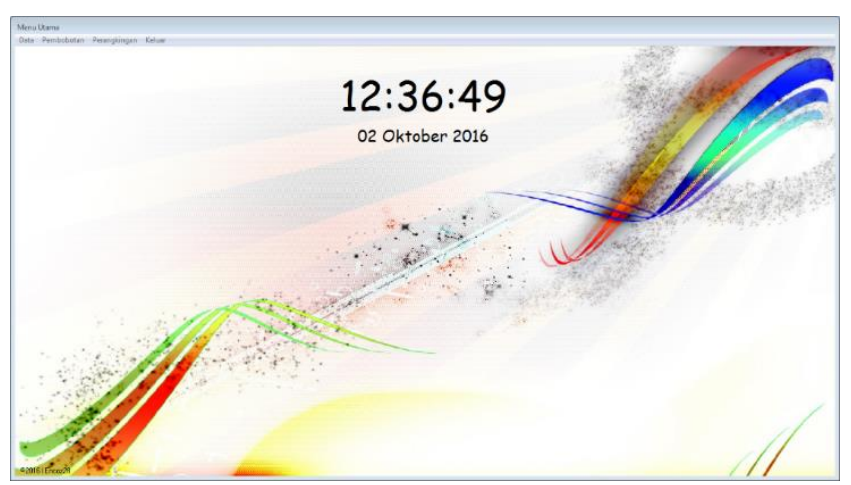

Gambar 4 Form Menu Utama 2

\subsection{Form Data Dosen}

Form data dosen berfungsi untuk melihat, tambah, edit, dan hapus data-data dosen. Dapat dilihat pada Gambar 5 .

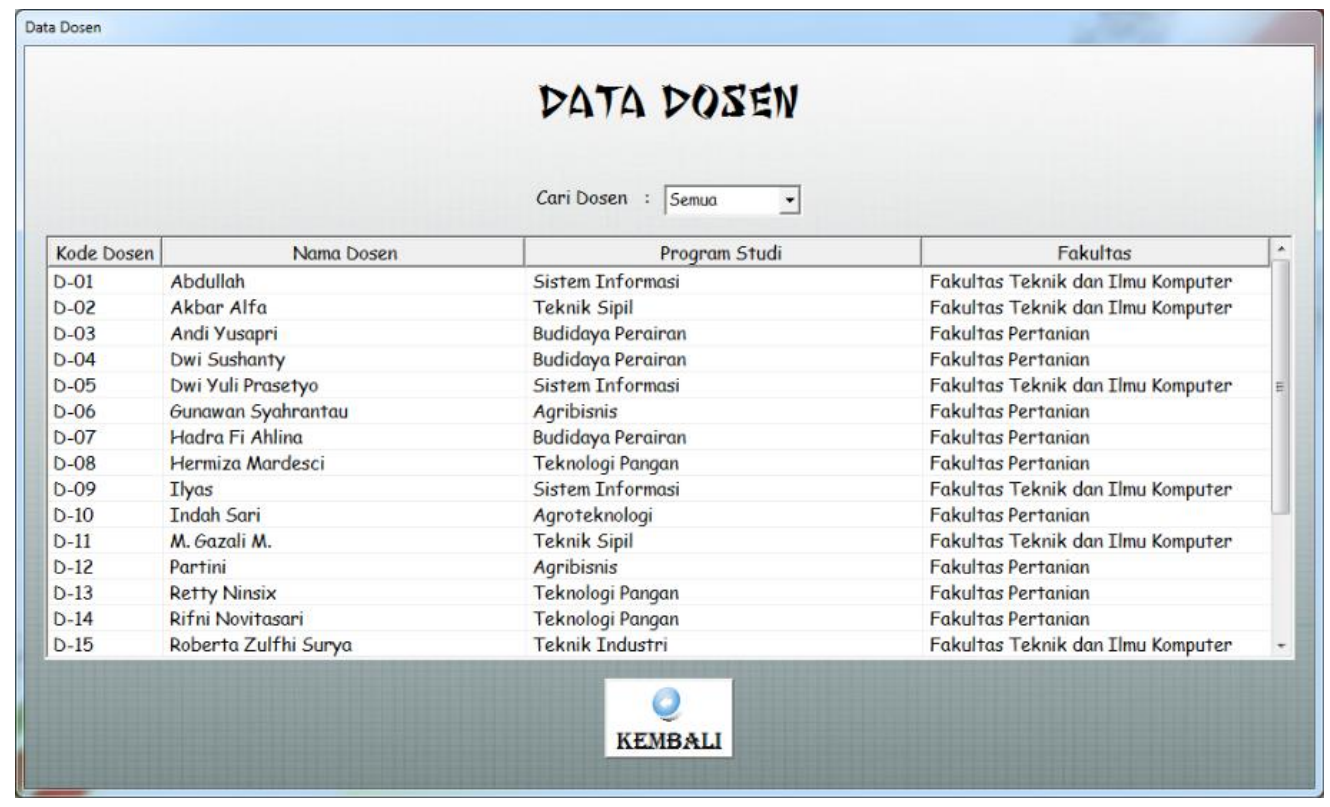

\section{Gambar 5 Form Data Dosen}

Ramadona, Kombinasi Metode Analytical Hierarchy Process (AHP) Dan Metode Simple Additive Weighting (SAW) Pada Penilaian Kinerja Dosen 


\subsection{Form Pembobotan Masing-Masing Kriteria}

Form pembobotan masing-masing kriteria berfungsi untuk masukkan nilai perbandingan antar kriteria yang didapat dari kuesioner yang telah disebar. Dapat dilihat pada Gambar 6.

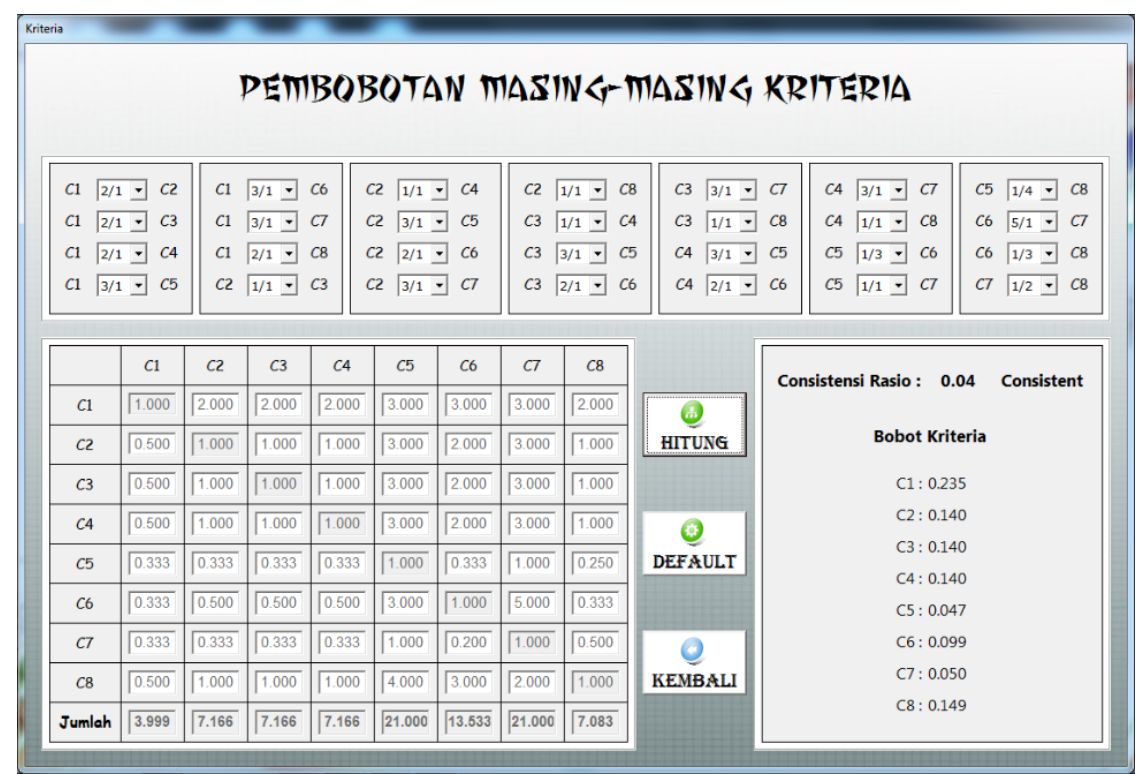

Gambar 6 Form Pembobotan Masing-Masing Kriteria

\subsection{Form Nilai Dosen}

Form nilai dosen berfungsi untuk melihat, tambah, edit, dan hapus data nilai-nilai dosen. Dapat dilihat pada Gambar 7.

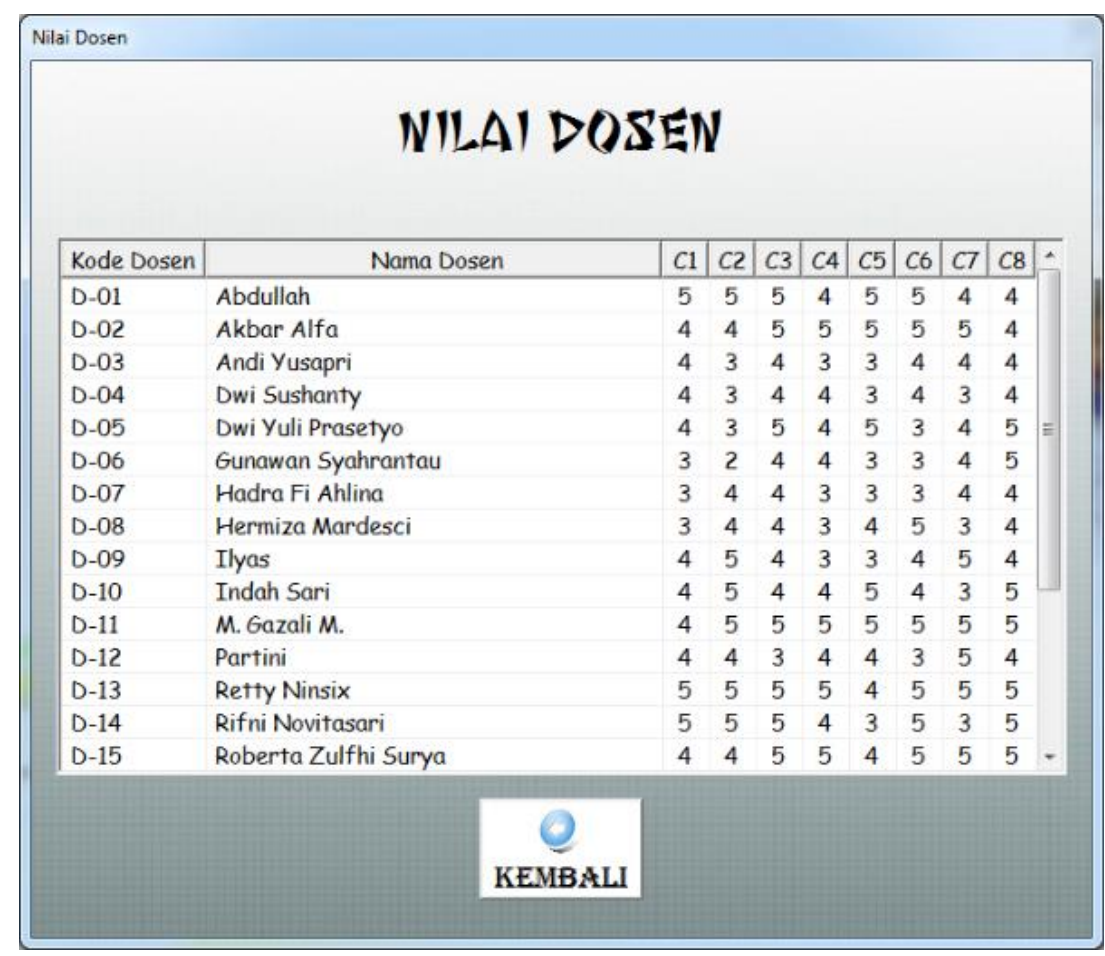

\section{Gambar 7 Form Nilai Dosen}




\subsection{Form Perangkingan}

Form perangkingan berfungsi sebagai hasil akhir dari semua perhitungan. Dapat dilihat pada Gambar 8.

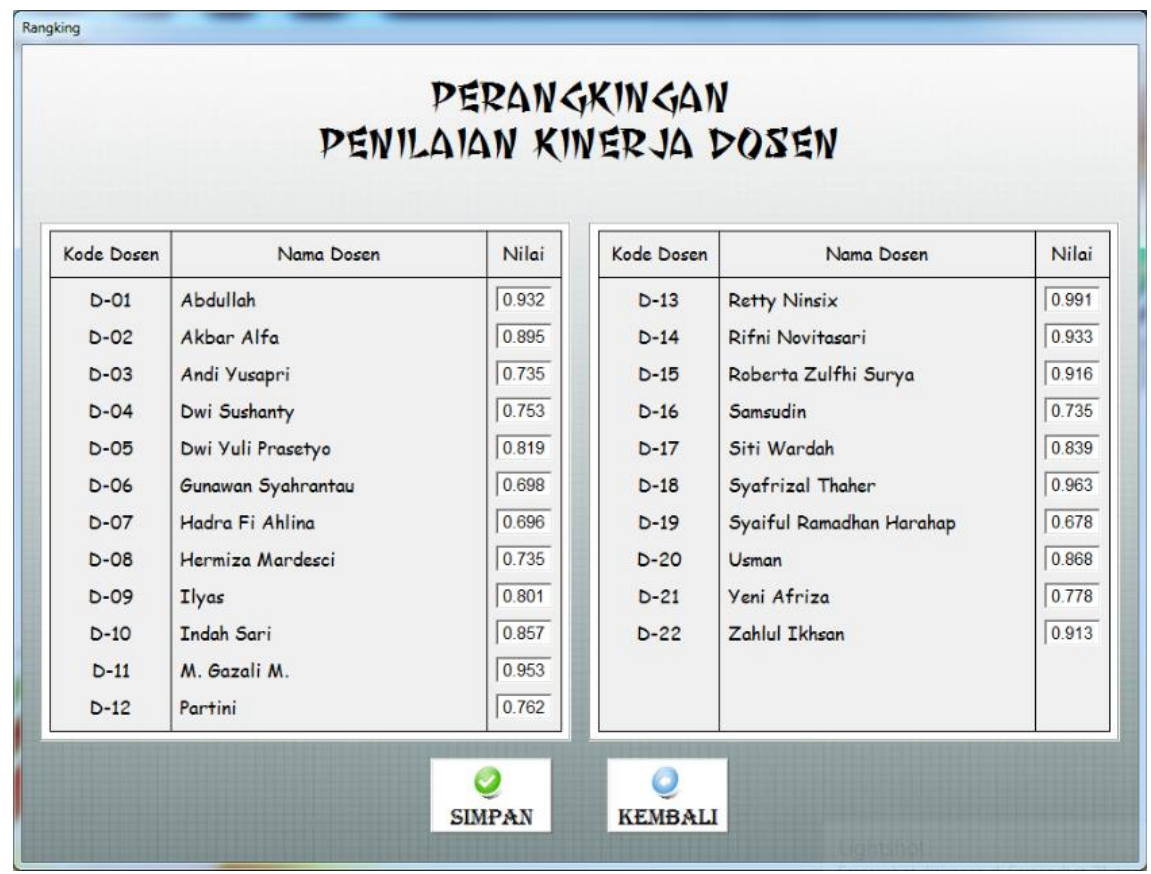

\section{Gambar 8 Form Perangkingan}

Perhitungan menggunakan sistem ini yaitu hasilnya sama persis dengan perhitungan menggunakan Microsoft Excel 2013 pada perancangan di atas.

\subsection{Form View}

Form view berfungsi untuk membuka kembali atau melihat data yang telah tersimpan. Dapat dilihat pada Gambar 9.

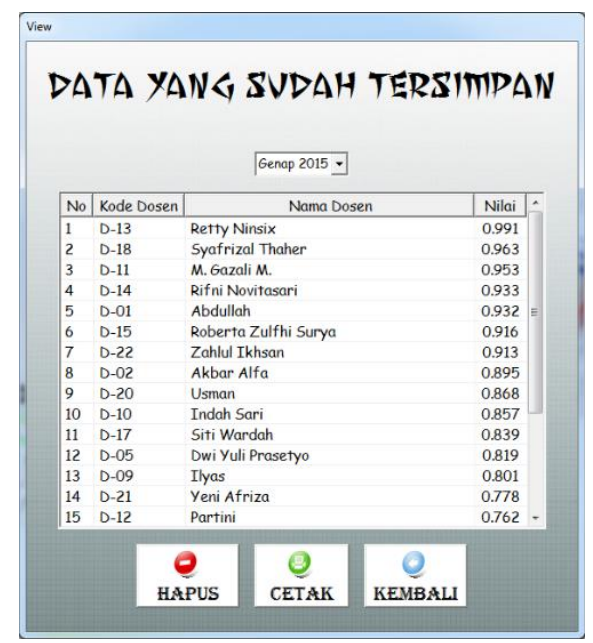

\section{Gambar 9 Form View}

\subsection{Form Cetak}

Form cetak berfungsi sebagai tampilan output dari perangkingan, dan output ini bisa di print. Dapat dilihat pada Gambar 10. 


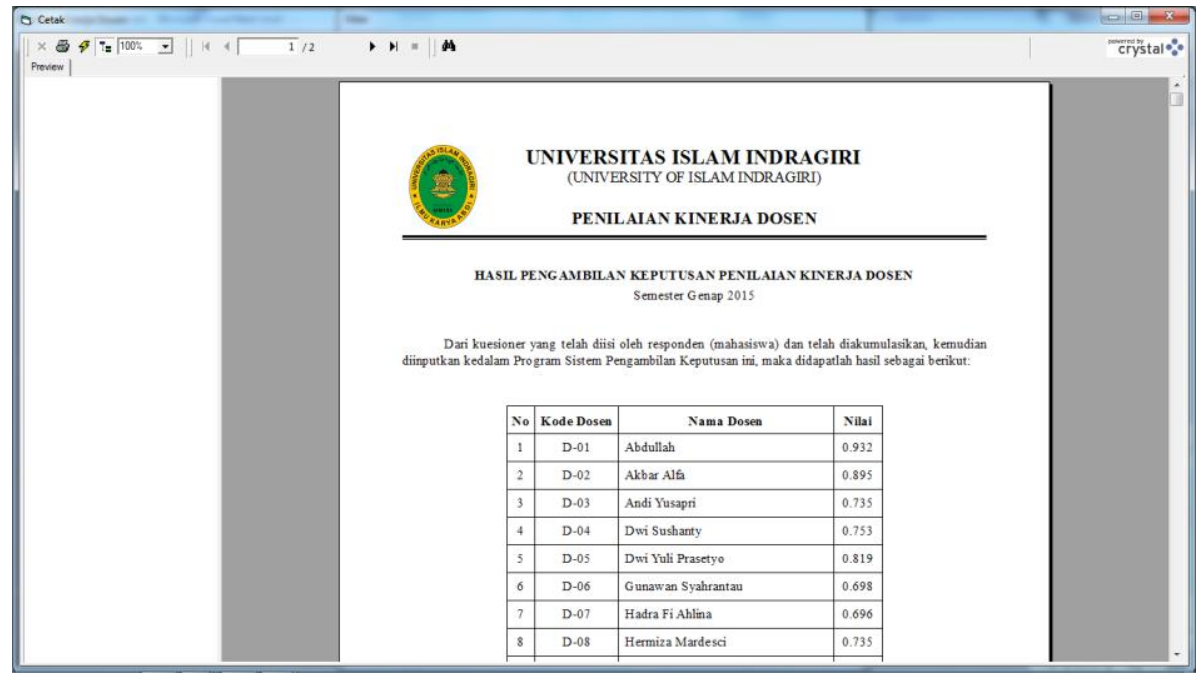

Gambar 10 Form Cetak

\section{KESIMPULAN}

Beberapa hal yang dapat disimpulkan dari penilitian skripsi ini adalah sebagai berikut: (1). Aplikasi sistem pendukung keputusan untuk penilaian kinerja dosen ini berjalan dengan baik dan layak untuk diimplementasikan di LPMI Universitas Islam Indragiri; (2). Pengkombinasian antara metode AHP dan metode SAW bisa diaplikasikan untuk penilaian kinerja dosen.

Saran-saran yang dianggap perlu dikemukakan untuk pengembangan sistem pendukung keputusan kombinasi metode AHP dan metode SAW pada penilaian kinerja dosen antara lain: (1). Diharapkan dapat mengenalkan sistem pendukung keputusan dengan mengkombinasikan antara metode AHP dan metode SAW untuk penilaian kinerja dosen ini kepada LPMI Universitas Islam Indragiri, sehingga LPMI Universitas Islam Indragiri dapat merasakan manfaat bahwa bergunanya SPK dalam kehidupan sehari-hari; (2). Diharapkan kedepannya bisa merancang sistem pendukung keputusan dengan mengkombinasikan antara metode AHP dan metode SAW untuk penilaian kinerja dosen menggunakan bahasa pemograman lainnya.

\section{REFERENSI}

Asfi, M., \& Sari, R. P. (2010). Sistem Penunjang Keputusan Seleksi Mahasiswa Berprestasi Menggunakan Metode AHP. Informatika, 131-144.

Eniyati, S. (2011). Perancangan Sistem Pendukung Pengambilan Keputusan untuk Penerimaan Beasiswa dengan Metode SAW (Simple Additive Weighting). Teknologi Informasi DINAMIK, 171177.

Februariyanti, H., \& Zuliarso, E. (2012). Rancang Bangun Sistem Perpustakaan untuk Jurnal Elektronik. Teknologi Informasi DINAMIK, 124-132.

Kristanto, A. (2008). Perancangan Sistem Informasi dan Aplikasinya. Yogyakarta : Gava Media.

Kurniady, R. K., \& Munggana, W. (2013). Sistem Perbandingan dan Penyediaan Informasi Kendaraan Mobil dengan Metode AHP. 29.

Kusrini. (2007). Konsep dan Aplikasi Sistem Pendukung Keputusan. Yogyakarta: Andi.

Marimin, \& Maghfiroh, N. (2010). Aplikasi Teknik Pengambilan Keputusan dalam Manajemen Rantai Pasok. Bogor: IPB Press.

Nasution, S. R. (2013). Proses Hirarki Analitik dengan Expert Choice 2000 untuk Menentukan Fasilitas Pendidikan yang Diinginkan Konsumen. Teknik FTUP, 68-80. 
Saragih, S. H. (2013). Penerapan Metode Analitycal Hierarchy Process (AHP) pada Sistem Pendukung Keputusan Pemilihan Laptop. Pelita Informatika Budi Darma, 82-88.

Sihaloho, S. (2014). Sistem Pendukung Keputusan Penentuan Lokasi Pembangunan Tower Base Transceiver Station (BTS) pada Telkomsel dengan Metode Analytic Hierarchy Process (AHP). Informasi dan Teknologi llmiah (INTI), 83-90.

Suprianto, A. (2014). Sistem Pendukung Keputusan (SPK) Pemilihan Sepeda Motor Menggunkan Metode (AHP) dengan Pemodelan (UML). Sistem Informasi, 5-31.

Supriyono, Wardhana, W. A., \& Sudaryo. (2007). Sistem Pemilihan Pejabat Struktural dengan Metode AHP. SDM Teknologi Nuklir, 311-312.

Suryadi, K., \& Ramdhani, M. A. (2002). Sistem Pendukung Keputusan. Bandung: PT Remaja Rosdakarya.

Suryantara, I. (2014). Merancang Aplikasi Akuntansi dengan VB.Net. Jakarta: PT Elex Media Komputindo.

Tobing, G. L. (2014). Sistem Pendukung Keputusan Pemilihan Jurusan pada Sekolah Menengah Kejuruan (SMK) Negeri 1 Siatas Barita dengan Metode Simple Additive Weighting (SAW). Informasi dan Teknologi Ilmiah (INTI), 112-117.

Usito, N. J. (2013). Sistem Pendukung Keputusan Penilaian Proses Belajar Mengajar Menggunakan Metode Simple Additive Weighting (SAW). Sistem Informasi, 6-13.

Zulita, L. N. (2013). Sistem Pendukung Keputusan Menggunakan Metode SAW untuk Penilaian Dosen Berprestasi (Studi Kasus di Universitas Dehasen Bengkulu). Media Infotama, 101. 